\title{
ASSESSING THE SUITABILITY OF SITES FOR RECLAIMED WATER RECHARGE USING HYDROGEOPHYSICAL AND HYDROCHEMICAL ANALYSIS
}

\section{SELVAKUMAR T.* \\ MADHAVI G. MATHIAZHAGAN M.}

Received: 09/01/2015

Accepted: 07/04/2015

Available online: 03/06/2015
Centre for Water Resources

Anna University, Chennai-600025, India

\section{ABSTRACT}

An electrical resistivity survey was carried out in the premises of Chennai Metrowater Sewage treatment plants and Anna University to assess the suitability of underlying aquifer for reclaimed water recharge and also to understand groundwater conditions. The geo-electrical methods used in the survey are Vertical Electrical Sounding (VES) using the Schlumberger Configuration. The instrument used is ABEM Terrameter SAS 1000. The VES data from 5 locations were interpreted using IX1DV2 software. The resistivity varies from $3.96 \Omega \mathrm{m}$ to $2796 \Omega \mathrm{m}$ while the thickness varies from $0.58 \mathrm{~m}$ to $43.05 \mathrm{~m}$. The EC value for VES 1 and VES 3 are $26400 \mu \mathrm{Sm}^{-1}$ and $1551 \mu \mathrm{S} \mathrm{cm}^{-1}$, the TDS value for VES 1 and VES 3 are 16,896 $\mathrm{mg} \mathrm{l}^{-1}$ and $993 \mathrm{mg} \mathrm{l}^{-1}$ respectively. From this investigation, the thickness of the first layer obtained by VES method along with clay and sand ratio is the deciding factor to assess the suitability of reclaimed water recharge. The study reveals that the Clay and Sand \% should be between $30-40$ and 60 - 70 respectively for reclaimed water recharge. Koyambedu and Anna University STP and surrounding area are found suitable for reclaimed water recharge using Soil Aquifer Treatment.

Keywords: Chennai Sewage Treatment Plants - reclaimed water recharge - Vertical Electrical Sounding Aquifer - Water Quality

\section{Introduction}

Groundwater use is increasing all over the world and India is not an exception. Many aquifers are overexploited with abstraction exceeding recharge. In this context, groundwater availability can be increased by reusing reclaimed water for recharge. Surface spreading is the simplest, oldest and most widely applied method of artificial recharge to groundwater.

Reclaimed water is an ever more valued non-conventional water resource. This is especially true in the arid and semi-arid zones of the Earth where water is scarce. Among the possibilities of wastewater reuse, groundwater recharge is one of the most promising methods (Asano and Cotruvo J.A. 2004). Where hydrogeological conditions are favourable, wastewater reclamation can be implemented in a simple way by the Soil Aquifer Treatment (SAT) process. As wastewater percolates through the vadose zone, and then moves some distance laterally through the aquifer, additional treatment is provided to the water, mainly through filtration processes.

At present, some concerns regarding health risk considerations have limited the expanding use of reclaimed municipal water for groundwater recharge, especially if a large portion of the aquifer contains reclaimed water that may enter the domestic water supply (Ange A.N. et al., 1996) 
The SAT process should be designed and managed to avoid encroachment into the native groundwater and to use only a portion of the aquifer. The distance between infiltration basins and wells should be as great as possible, usually at least 50-100 m and transit (residence) time must last from 3 to 6 months to give adequate treatment. The ability of the subsoil and bedrock to treat pollutants adequately depends on the geological and hydrogeological characteristics of the site, particularly the permeability (including the soil one), the thickness of the subsoil and the depth to the water table. As reclaimed water migrates from land surface, it first moves through an unsaturated soil profile zone before recharging the saturated groundwater system. When water moves through the unsaturated zone (including soil), physical and chemical processes occur that affect the water (and potential contaminants) volume and rate of movement. Aquifers associated with thick unsaturated zones (deep water tables) tend to have less recharge than aquifers with thinner unsaturated zones where the water retention time is less. Soil and subsoil provide the most effective protection of groundwater form pollution. Organic and clayey soil, and clayey sands/gravels and permeable sands (i.e combination of sand, silt and clay) are the most suitable sub soils for effluent disposal and treatment. In contrast, once pollutants enter bedrock the rate of purification declines. Groundwater is most vulnerable and at risk from pollution where bedrock, particularly limestone, is at or close to the surface: where clean, permeable sand/gravel underlies the site; and in sand/gravel where the water table is close to the surface. In areas with these conditions, pollution of wells is common. Therefore, these pedological, geological and hydrogeological characteristics should be examined and mapped in detail, thereby providing a soil and subsoil assessment for any area or site. Modern geophysical methods, such as vertical electrical sounding, can play an important role in these studies (Tapias J.C., et al. 2005).

The resistivity methods especially the VES method have been used successfully for investig ating groundwater quality in different lithological settings because the instrumentation is simple, field logistics are easy and the analysis of data is straight forward compared to other methods (Zohdy et al., 1974; Stampolidis et al., 2005; Kalisperi et al., 2009). The VES survey technique has also been used effectively for the study of groundwater conditions, assessment of the sub-surface geoelectrical layers, thickness and depth of water bearing formation (Shankar, 1994; Lashkaripour, 2003; Oseji et al., 2006; Sahu and Sahoo 2006). The resistivity of a geological structure can vary significantly, depending on the porosity, water content and the concentration of salts in groundwater. Further the resistivity for different materials is not unique. Resistivity of water may vary from 0.2 to over $100 \Omega \mathrm{m}$ depending on its ionic concentration and the amount of dissolved solids (Palacky, 1987). Resistivity of natural water and sediments without clay vary from 1 to $120 \Omega \mathrm{m}$ (Zhodhy and Martin, 1993). Hence, the lithology and groundwater quality effects can not be differentiated by the geoelectric resistivity survey alone (Choudhury and Saha, 2004). For an effective use of VES survey, correlation with the in-situ groundwater chemistry obtained by sample collection is required. A combination of hydrogeological, geophysical and hydrochemical investigations can be very effective in the detection of contaminant migration (Sankaran et al., 2005; Sahebrao Sonkamble et al., 2004) as well as to suggest long-term remediation plan.

The electrical resistivity technique involves the measurement of the apparent resistivity of soils and rock as a function of depth or position. The most common electrical technique needed in hydrogeologic and environmental investigations is vertical electrical soundings (resistivity sounding). During resistivity surveys, current is injected into the reach through a pair of current electrodes, and the potential difference is measured between a pair of current electrodes, and the potential electrodes (Srinivas $Y$ et al., 2013; Alabi et al., 2010; Barry J.Hibbs, 2001; Daniel W.Urish, 1983; Mark Stewart et al., 1983). The bulk average resistivity of all soils and rock influences the current flow. It is calculated by dividing the measured potential difference by the input current and multiplying by a geometric factor specific to the array being used and electrode spacing (Mathiazhagan M. et al., 2012 \& 2013; Senthilkumar et al., 2012; Sikandar P, et al., 2010).

For this investigation, the methods used included surface geophysical survey, collection and analysis of water quality data from borewells and lithology data/water quality data from Government and private agencies (Sivaraman K.R. et al., 2002). The underlying objective of this investigation was to test the 
advantage of using this geophysical method for the continuous characterization of the subsoil structure and to ascertain the suitability of reclaimed water recharge around the Chennai Sewage Treatment Plants.

\section{Material and Methods}

\subsection{Study Area}

Chennai is the capital of Tamilnadu. The increase in population density coupled with industrial development has given rise to a greater demand far-exceeding the available resources Chennai district (fig. 1 ) is bounded by latitudes $13^{\circ} 02^{\prime} 30^{\prime \prime}$ to $13^{\circ} 14^{\prime} 0^{\prime \prime}$ and longitudes $80^{\circ} 12^{\prime} 00^{\prime \prime}$ to $18^{\circ} 18^{\prime} 30^{\prime \prime}$. The geographical area of Chennai city is 176 Sq.Km while Chennai metropolitan area (CMA) is 1189 Sq.Km. At present, nine Treatment Plants treat the sewage secondarily by Activated sludge process with a capacity of 486 MLD. Further, the works are under progress for an additional capacity of 234 MLD.

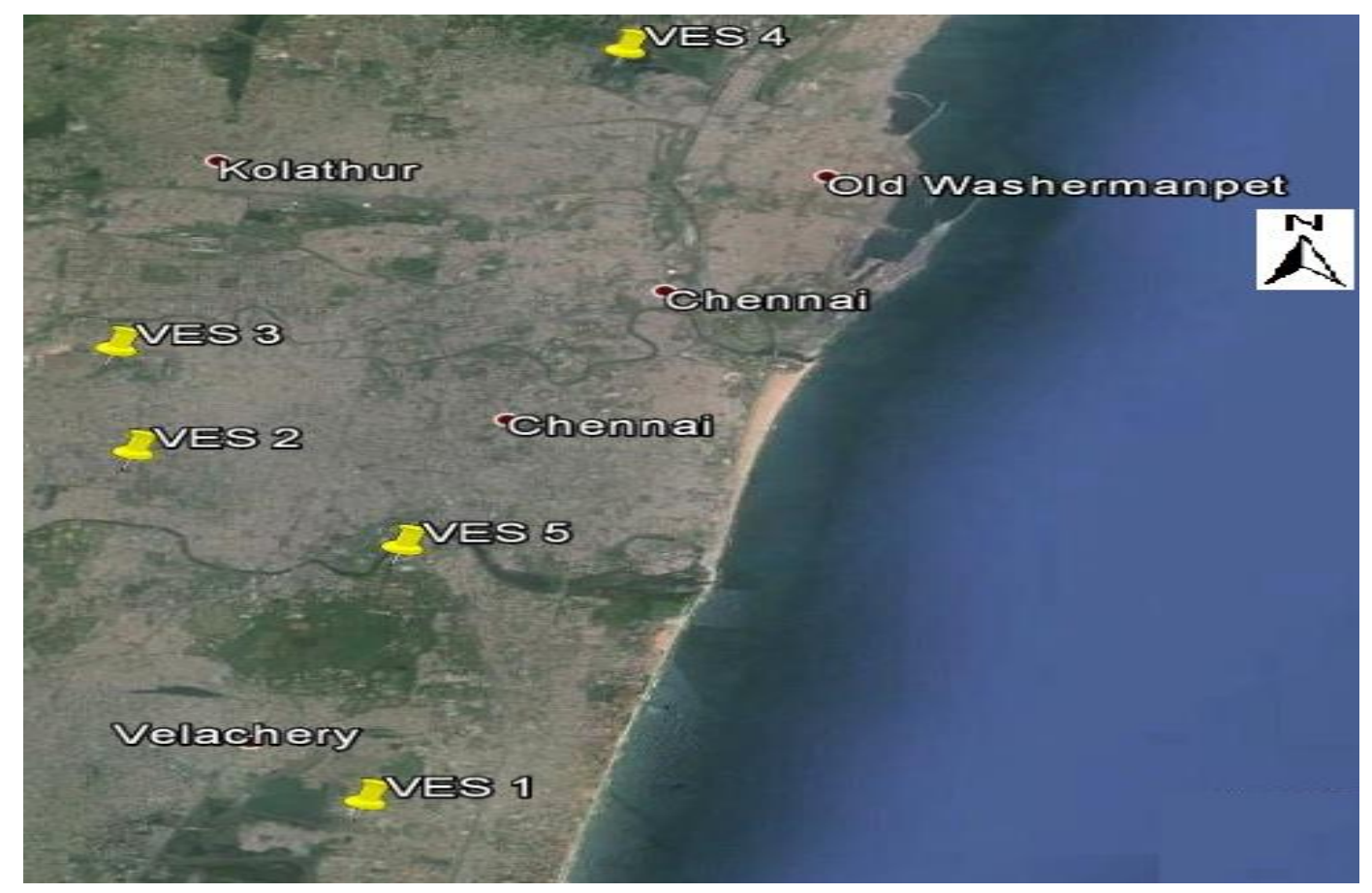

Figure 1. Satellite image of VES locations in study area

Only $36 \mathrm{MLD}$ of this secondary treated sewage water is being supplied to the industries in North Chennai. The secondary treated wastewater from STPs are discharged into streams fulfilling the Central Pollution Control Board (CPCB) norms. Groundwater has been overexploited in Chennai. A good possibility exists to recharge artificially the excess treated wastewater through SAT and use the recharged water for purposes other than drinking.

\subsection{Hydrometeorology}

The annual rainfall in Chennai is in the range of $1200-1300 \mathrm{~mm}$. The rainfall generally occurs during short spells with high intensity. Because of the short duration, most of the rainfall is wasted through runoff leaving a small portion to recharge the groundwater system. Chennai district enjoys a tropical climate with mean annual temperature of $24.3^{\circ} \mathrm{C}$ to $32.9^{\circ} \mathrm{C}$. The temperature is usually in the range of $13.9^{\circ} \mathrm{C}$ to $45^{\circ} \mathrm{C}$. The humidity is usually in the range of 58 to $84 \%$.

\subsection{Soil Type}

The major soil types encountered in the metropolitan area are alluvial, clay and loamy soils. Alluvial soils are commonly observed in the central part along the flood plains of rivers Cooum and Adyar in coastal 
area and have high permeability. Clayey skeletal soils are seen in the Northern part of the metropolitan area. These soils are alkaline in nature, have poor permeability and are highly calcareous and cracking.

\subsection{Geology and hydrogeology}

Chennai district is underlain by various geological formations from ancient Archaeans to the recent alluvium. The geological formations of the district can be grouped into three units namely i) Archean Crystalline rocks, ii) consolidated Gondwana and Teritary sediments and iii) unconsolidated recent alluvium. Most of the geological formations are concealed due to overlying alluvial materials excepting for a few exposures of crystalline rocks like charnockites.

The crystalline rocks are weathered and jointed/fractured. The degree and depth of weathering varies from place to place and the thickness of weathered mantle varies from less than a metre to about $12 \mathrm{~m}$ in this district. The Gondwana shales are black to dark grey in colour and are jointed and fractured. They are encountered in a number of boreholes and their thickness varies form $24 \mathrm{~m}$ in Kilpauk area through $20 \mathrm{~m}$ in Ashok Nagar area to more than 130 in Koyambedu area. All these areas are in the north wastern part of Chennai city.

The occurrence of tertiary deposits in Chennai is not well demarcated. However, the sand stones encountered in some of the boreholes below alluvium. Groundwater in Chennai district occurs in all the geological formations viz. the Archaean crystalline, Gondwana, Tertiaries and alluvium and is developed by means of ring wells, dug wells, filter point wells, borewells and tube wells (Central Groundwater Board).

\subsection{Studies carried out}

The resistivity technique examines horizontal and vertical discontinuities in the electrical properties of the ground. It measures earth resistivity by passing an electrical current into the ground and measuring the resulting potentials created. This method involves the supply of direct current or low-frequency alternating current into the ground through a pair of electrodes and the measurement of the resulting potential through another pair of electrodes (potential electrodes) (Zohdy, 1974). Because the current is known and the potential can be measured, an apparent resistivity can be calculated. The apparent resistivity of the subsurface material is a function of the magnitude of the current, the recorded potential difference and the geometry of the electrode array used. The current electrodes spacing ( $A B)$ increases after each reading while the potential electrodes spacing $(\mathrm{MN})$ increases only when deemed necessary and controlled by the relation $A B / 2 \geq 5 \mathrm{MN} / 2$ as required by the Schlumberger array.

For Schlumberger soundings (fig. 2), this survey was conducted with ABEM SAS 1000 Terrameter. Then, the sounding curves were interpreted to determine the true resistivities and thicknesses of the subsurface layers. For interpretation, IX1Dv2 software was used.

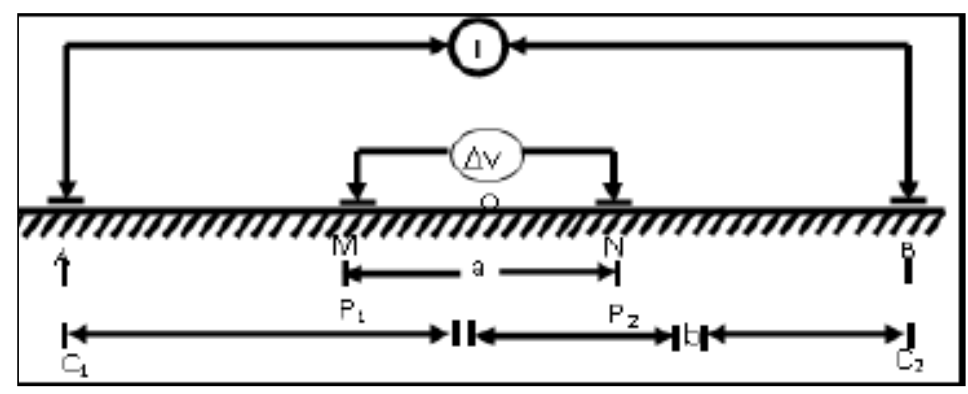

Figure 2. Schlumberger Sounding or Vertical Electrical Sounding (VES)

A total number of 5 Vertical Electrical Sounding (VES) were carried out in the Chennai STP's namely Perungudi, Nesapakkam, Koyambedu, Kodungaiyur and Anna University. The maximum outer current electrode spacing $200 \mathrm{~m}$ and inner potential electrode spacing $10 \mathrm{~m}$ were used. The apparent resistivity data are associated with varying depths relative to the distance between the current and potential electrodes and can be interpreted qualitatively and quantitatively in terms of a lithologic and/or 
geohydrologic model. In the qualitative interpretation method the shape of the field curve is observed to assess the number of layers and their resistivity. In the quantitative interpretation method, true resistivity ' $\rho$ ' and layer thickness ' $h$ ' as the fundamental characteristics of a geoelectric layer are obtained. The quantitative interpretation of VES curves in this study was done by the well-known method of curve matching. In curve matching technique, the field VES curves are compared with set of theoretical curves to obtain ' $\rho$ ' and ' $h$ '. Soil and Water samples were taken for analysis of lithological and hydrogeological information and chemical analysis of the groundwater was carried out. These data were used to evaluate the subsurface hydrogeological and lithological conditions and to correlate/calibrate field VES survey curves at these sites.

\subsection{Geochemical method}

The present study provides a detailed description of the chemical criteria of soil sample and groundwater sample. Five soil and groundwater samples were collected from the study area. Soil samples from five STP were collected from depth ranging between 0 and $0.75 \mathrm{~m}$ (referred to as top soil). The selection of the depth range was based on the fact that previous studies indicated that most of the purification takes place at the upper most layer of the soil. It is the natural soil that has been collected from the STP without any treatment. The groundwater samples were collected from bore wells as near as possible to VES locations to correlate between electrical resistivity measured from geophysical method and electrical conductivity and other chemical parameters measured from chemical analysis of water samples. The water samples were collected from the borewells. The samples were analyzed using standard procedures (APHA 1989). Immediately, after sampling EC and TDS was measured in the field using a pen type digital EC and TDS meter which was calibrated using standard buffer solution as per manufacturer instructions. In situ electrical conductivity and TDS were measured with the (EQ 8361 EQUINOX pen type EC/TDS) probe meter.

\section{Results and Discussion}

The results of data analysis are presented as sounding curves, tables of geoelectric parameters. The predominant field curve in the area is the $\mathrm{H}$ type and $\mathrm{H}$ type combination curve, a three layer and four layer setup (fig. 3). Table 1 shows that the study area is underlined by three and four geoelectric layers. The first layer with topsoil has a variation among the STPs. The second layer is shallow and unconfined aquifer with Sandy clay, Sand and Weathered charnockite rock. The third layer is fracture aquifer with Sandy clay, Sand, Shale and Weathered/Fractured charnockite rock. And the fourth layer is deep fractured/massive charnockite rock. Five sets of readings (from VES 1 to VES 5) were taken for Vertical Electrical Sounding (VES) and with these readings the value of apparent resistivity $\left(\rho_{a}\right)$ was found out. The $\rho_{a}$ value indicates the geological aspects that is type of lithology and type of water present in the aquifer. The EC value for VES 1 and VES 3 are $26400 \mu \mathrm{cm}^{-1}$ and $1551 \mu \mathrm{S} \mathrm{cm} \mathrm{cm}^{-1}$, the TDS values for VES 1 and VES 3 are $16,896 \mathrm{mg} \mathrm{l}^{-1}$ and $992.64 \mathrm{mg} \mathrm{l}^{-1}$ respectively.

Table 1. Summary of modeling results for all soundings

\begin{tabular}{|c|c|c|c|c|c|c|c|c|c|c|}
\hline Stations & ра 1 & ра 2 & ра 3 & ра 4 & h1 & h2 & h3 & Depth & $\begin{array}{l}\text { Type } \\
\text { Curve }\end{array}$ & $\begin{array}{l}\text { RMS } \\
\text { Error }\end{array}$ \\
\hline VES 1 & 446 & 7.6 & 1060 & - & 0.69 & 43.05 & - & 44.43 & $\mathrm{H}$ & 8.3 \\
\hline VES 2 & 702 & 7.6 & 508 & - & 0.58 & 28.97 & - & 29.55 & $\mathrm{H}$ & 6.8 \\
\hline VES 3 & 9.95 & 3.97 & 21 & 2796 & 2.31 & 11.95 & 9.98 & 24.24 & $\mathrm{HA}$ & 13.4 \\
\hline VES 4 & 12.1 & 3.96 & 7.51 & 1950 & 1.81 & 13.12 & 7.64 & 22.57 & $\mathrm{HA}$ & 10.6 \\
\hline VES 5 & 21.6 & 11.9 & 315 & 53.7 & 0.89 & 4.71 & 8.49 & 14.09 & $\mathrm{HK}$ & 3.4 \\
\hline
\end{tabular}

Perungudi, Nesapakkam, Koyambedu, Kodungaiyur and Anna University VES 1 to VES 5 respectively. 


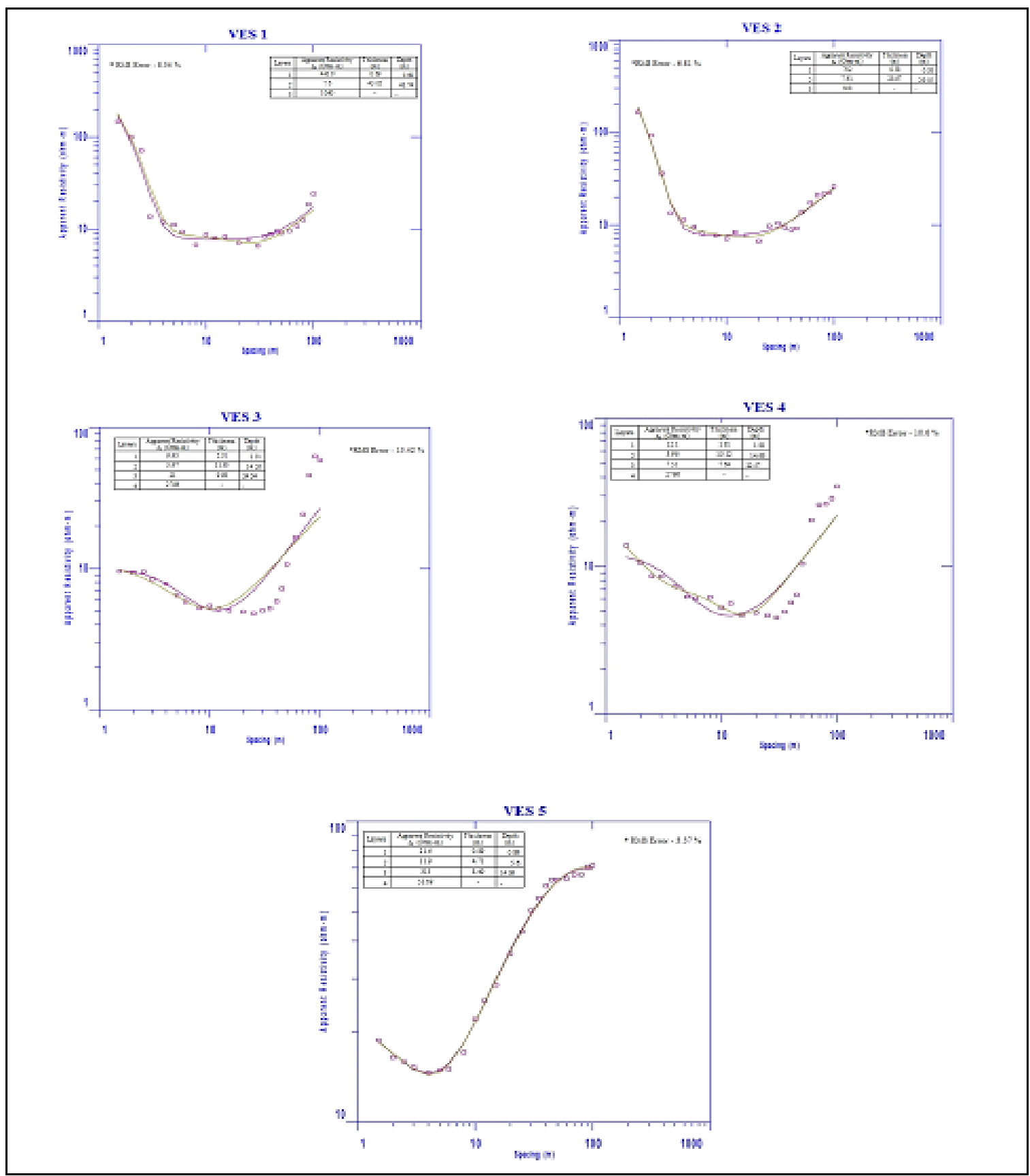

Figure 3. Vertical Electrical Sounding Interpretation results

If the apparent resistivity value for water is 10 to $100 \Omega \mathrm{m}$, the water is of potable use and if the value is above or below this range the water is not fit for potable use. In this case apparent resistivity range from $3.96 \Omega \mathrm{m}$ to $2796.4 \Omega \mathrm{m}$. Almost all the VES locations except VES 5 and VES 3 were totally polluted. Ultimately it is not fit for potable purpose.

\subsection{Perungudi STP}

The field curve (VES1) was observed to be of H Type showing three layers. The resistivity of the first, second and third geo-electric layers were found to change from $446 \Omega \mathrm{m}$ to $7.6 \Omega \mathrm{m}$ and $1060 \Omega \mathrm{m}$. The first layer represented the topsoil of thickness $0.69 \mathrm{~m}$ followed by weathered rock for a thickness of $43 \mathrm{~m}$ and then bedrock. The EC and TDS values in borewell water at Perungudi STP were the highest with the values of $26400 \mu \mathrm{S} \mathrm{cm}^{-1}$ and $16,896 \mathrm{mg} \mathrm{l}^{-1}$ among the 5 STPs Table 2. This high value is due to the effect of 
Buckingham Canal. The saline water present in the unlined Buckingham Canal seeps and increase the salt concentration in the top layer of water in its vicinity on either side of of Buckingham Canal and also due to the clayey nature of the formation and to a great extent due to the dumping of solid and liquid waste. The quality of water is poor with high values of chloride $\left(10,574.44 \mathrm{mg} \mathrm{l}^{-1}\right)$ and sulphate $\left(2582.4 \mathrm{mg} \mathrm{l}^{-1}\right)$ Mathiazhagan $M$ et al., (2013) carried out 5 no.s of vertical electrical sounding at the Perungudi dumping yard near the State highway 109. Except VES 5. Top layer was found to be of madeup soil with 1.5 to $2 \mathrm{~m}$ depth. All, the VES location had 3 layers. The result showed that the groundwater was contaminated upto approximately 1.5 to $1.75 \mathrm{~km}$ spatially and $100 \mathrm{~m}$ depths. The apparent resistivity ranged from $0.2 \Omega \mathrm{m}$ to $3170 \Omega \mathrm{m}$. The TDS value for VES 4 and VES 5 are $3600 \mathrm{mg} \mathrm{l}^{-1}$ and $3800 \mathrm{mg} \mathrm{l}^{-1}$. The aquifer is not suitable for recharging reclaimed water at Perungudi STP.

\subsection{Nesapakkam STP}

The field curve was observed to be of $\mathrm{H}$ type showing three layers. The first layer represented the madeup soil with a resistivity of $702 \Omega \mathrm{m}$ with $0.58 \mathrm{~m}$ thickness, near the buffer zone of metal approach road. Second layer was observed to have a thickness of $28.97 \mathrm{~m}$ and a resistivity of $7.61 \Omega \mathrm{m}$ with the original soil of Sandy clay. The third layer is formed of Bed rock (charnockite) with the resistivity value of $508 \Omega \mathrm{m}$. The Gondwana sediments are represented by shales and clay. Though the subsurface formation is conducive for the reclaimed water recharge, the presence of iron bearing clay lenses contributes iron content to the groundwater. Hence the value for iron in the groundwater is $0.95 \mathrm{mg} \mathrm{l}^{-1}$, the highest among the 5 STPs. This condition is not favorable for reclaimed water recharge.

\subsection{Koyambedu STP}

The HA Type sounding curve indicated four geo-electrical layers. The first layer represented the top soil of clay with a resistivity of $9.95 \Omega \mathrm{m}$ and a depth of $2.31 \mathrm{~m}$. second layer was observed to have a thickness of $11.95 \mathrm{~m}$ and a resistivity of $3.97 \Omega \mathrm{m}$ with a soil comprising full of sludge. The third layer was about 9.98 $\mathrm{m}$ thick with a sandy clay formation. Shallow aquifer exists in this zone. The fourth layer is formed of bed rock with a resistivity of $2796 \Omega \mathrm{m}$. The EC, TDS and Chloride are the least among the 5 STPs with the values $1551 \mu \mathrm{S} \mathrm{cm}^{-1}, 992.64 \mathrm{mg} \mathrm{l}^{-1}$ and $182.5 \mathrm{mg} \mathrm{l}^{-1}$ respectively. When comparing all the $5 \mathrm{STP}^{\prime} \mathrm{s}$ the surrounding outside area at Koyambedu is having more vacant land and less pumping activities. Hence the subsurface formation is not polluted. This type of area is suitable for reclaimed water recharge.

\subsection{Kodungaiyur STP}

The field curve was observed to be of HA type showing four layers. The first layer represented the top soil with resistivity of $12.1 \Omega \mathrm{m}$ with a thickness of $1.81 \mathrm{~m}$. second layer was observed to have a thickness of $13.12 \mathrm{~m}$ and a resistivity of $3.96 \Omega \mathrm{m}$ with a sandy clay. Shallow aquifer. The third layer was about $7.64 \mathrm{~m}$ thick with a resistivity of $4.51 \Omega \mathrm{m}$ with a semi confined aquifer formed by claye-sand. The resistivity of the fourth layer was $1950 \Omega \mathrm{m}$ with bed rock formation. The presence of dumping yard in Kodungaiyur has the influence in EC and TDS values. The values are 8.34 and $5337.6 \mathrm{mg} \mathrm{l}^{-1}$ respectively the $2^{\text {nd }}$ largest value after Perungudi. This fact is reflected in the values of chloride and sulphate with $1413.18 \mathrm{mg} \mathrm{l}^{-1}$ and 1039 $\mathrm{mg} \mathrm{I}^{-1}$ respectively. Kodungaiyur STP is not suitable for reclaimed water recharge.

\subsection{Anna University STP}

The HK type sounding curve indicated four geo-electrical layers. The first layer represented the top soil of sandy clay with $0.89 \mathrm{~m}$ thickness and resistivity of $21.61 \Omega \mathrm{m}$. second layer was observed to have a thickness of $4.7 \mathrm{~m}$ and a resistivity of $11.9 \Omega \mathrm{m}$ with clayey sand. The third layer was found with a thickness of $8.49 \mathrm{~m}$ and resistivity of $315 \Omega \mathrm{m}$ with weathered rock. The fourth layer was found with a shallow aquifer with fractured rock having a resistivity of $53.69 \Omega \mathrm{m}$. Anna University STP bore water has the least value of iron and sulphate content among the 5 STPs with $0.08 \mathrm{mg} \mathrm{l}^{-1}$ and $104.9 \mathrm{mg} \mathrm{l}^{-1}$ respectively. This site is favourable for making reclaimed water recharge. 
Table 2. Selected water quality parameters from the Borewells located at 5 sewage Treatment plants (STPs) of Chennai.

\begin{tabular}{cccccccc}
\hline S.No & Parameters & Unit & STP 1* & STP 2 & STP 3 & STP 4 & STP 5 \\
\hline 1 & $\mathrm{pH}$ & & 7.2 & 8.1 & 7.2 & 7.7 & 7 \\
\hline 2 & $\mathrm{EC}$ & $\mu \mathrm{S} \mathrm{cm}^{-1}$ & 26400 & 3810 & 1551 & 8340 & 1711 \\
\hline 3 & $\mathrm{TDS}$ & $\mathrm{mg} \mathrm{l}^{-1}$ & 16896 & 2438 & 992 & 5337 & 1095 \\
\hline 4 & $\mathrm{TA}$ & $\mathrm{mg} \mathrm{l}^{-1}$ & 185 & 670 & 290 & 700 & 225 \\
\hline 5 & Iron & $\mathrm{mg} \mathrm{l}^{-1}$ & 0.44 & 0.95 & 0.27 & 0.27 & 0.08 \\
\hline 6 & Sulphate & $\mathrm{mg} \mathrm{l}^{-1}$ & 2582 & 209 & 135 & 1039 & 104 \\
\hline 7 & Chloride & $\mathrm{mg} \mathrm{l}^{-1}$ & 10575 & 664 & 182 & 1413 & 720 \\
\hline 8 & Nitrate & $\mathrm{mg} \mathrm{l}^{-1}$ & 0.4 & 0.7 & 1 & 1.9 & 7.1 \\
\hline
\end{tabular}

* Perungudi, Nesapakkam, Koyambedu, Kodungaiyur and Anna University are represented by STP 1 to STP 5 respectively.

\subsection{Correlation of VES results with existing boreholes}

The success of any geophysical survey depends on the calibration of the geophysical data with actual hydrogeological and geological ground truth information. To understand the relationship between geoelectric parameters (formation, thickness and resistivity) and hydrogeological characteristics of formations for the investigated area, the results of these soundings were correlated with the results of samples (Soil and Groundwater) collected from existing boreholes at the same sites. The results of the Schlumberger electrical soundings interpreted using computer software were found to be in close agreement with the hydrogeological sections fig. 4. The results from the analysis of VES data and existing borehole data corroborates perfectly with the lithology.

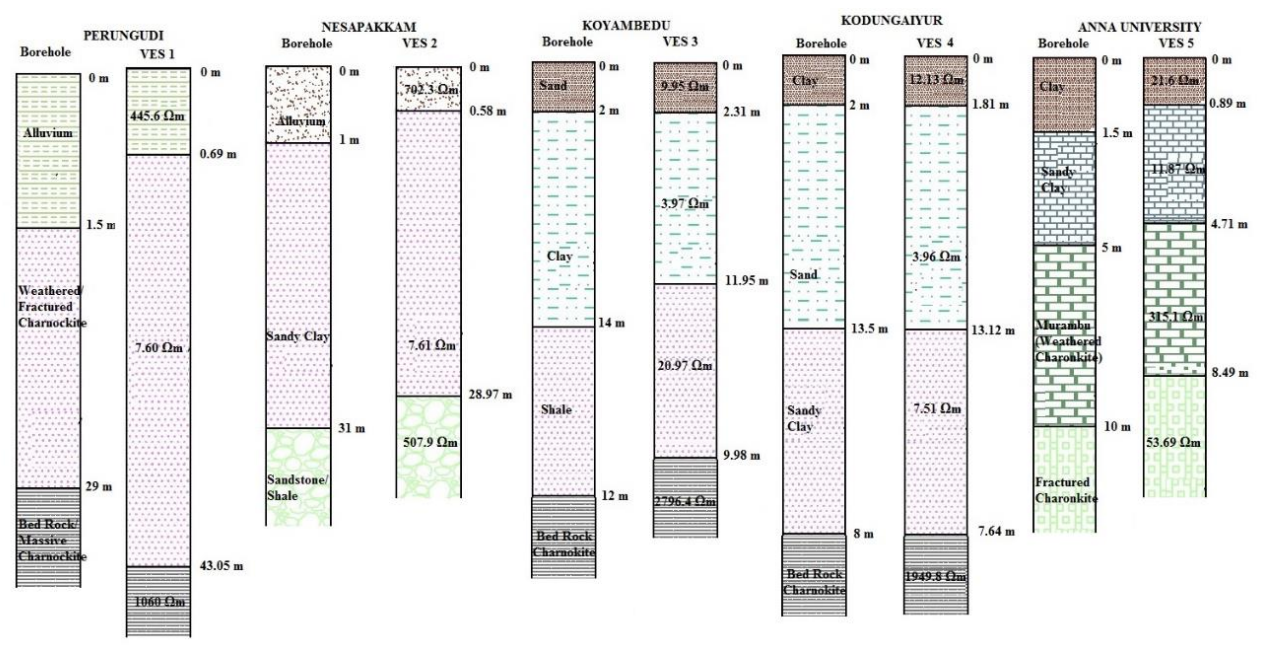

Figure 4. Geo electric section and Bore-log for the study area

\subsection{Integration of geophysical resistivity methods and soil textural classification}

Figs. $5 \mathrm{a}$ and $5 \mathrm{~b}$ indicate that the topsoil percent clay and topsoil percent sand influence the apparent resistivity. When the clay content is more, apparent resistivity is less, while the clay content is less, apparent resistivity is more. The particle size of the clay soil are very fine and less pore space is available and hence the apparent resistivity is influenced. Perungudi clay content is the least with $22 \%$ whereas the apparent resistivity value is $446 \Omega \mathrm{m}$. Kodungaiyur's clay content is the most with $33 \%$ where the apparent resistivity value is $12.1 \Omega \mathrm{m}$. Hence clay \% and apparent resistivity are indirectly proportional to each other.

The pore space in sandy particles are more when compared clay particles. Hence when the sand content is more, apparent resistivity is also more. While the sand content is less, the apparent resistivity is also less. Perungudi's sand content is $74 \%$, Kodungaiyur's sand content is the least with $50 \%$. Hence sand \% 
and apparent resistivity are directly proportional to each other. From this research it was found that the thickness of the first layer found out by VES methods along with the clay and sand \% ratio is useful to find the suitability of reclaimed water recharge area. The clay \% should be between 30 to 40 and sand \% should be between 60 to 70 for reclaimed water recharge.
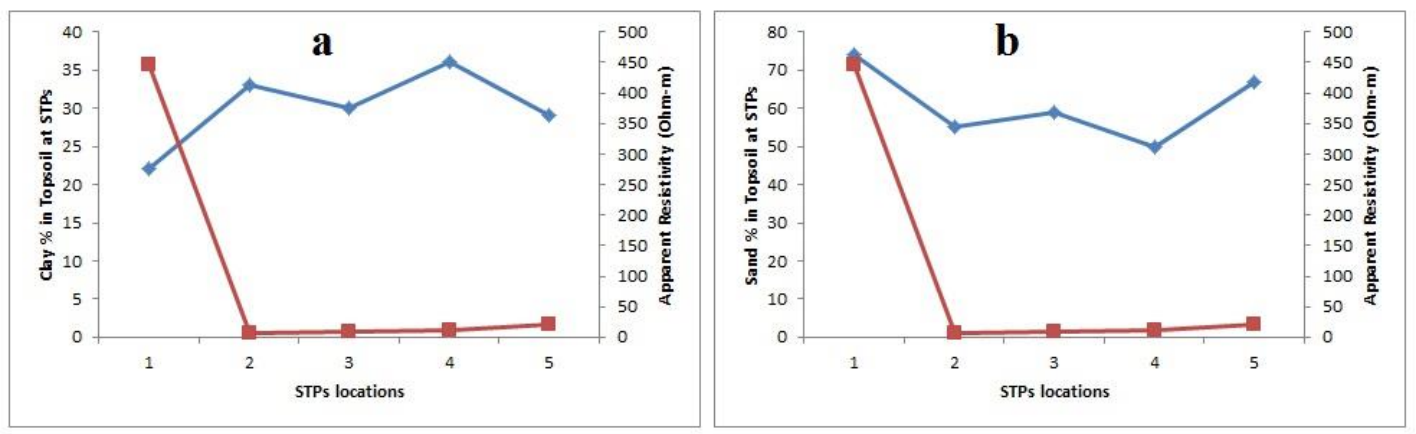

Figure 5. a) Top soil clay \% vs Apparent resistivity; b) Top soil sand \% vs Apparent resistivity

\subsection{Integration of geophysical resistivity methods and geochemical parameters}

The present studies allows the classification of groundwater based on pollution, salinity and apparent resistivity Table 3 shows the geophysical and geochmical parameters. The integration of electrical resistivity methods and geochemical analysis has revealed a good picture of groundwater quality in the study area. Because the resistivity and conductivity are inversely proportional to each other, the interpreted resistivity of the aquifer from geophysical methods, is low, whereas the electrical conductivity measured from geochmeical analysis is high as in Table 3.
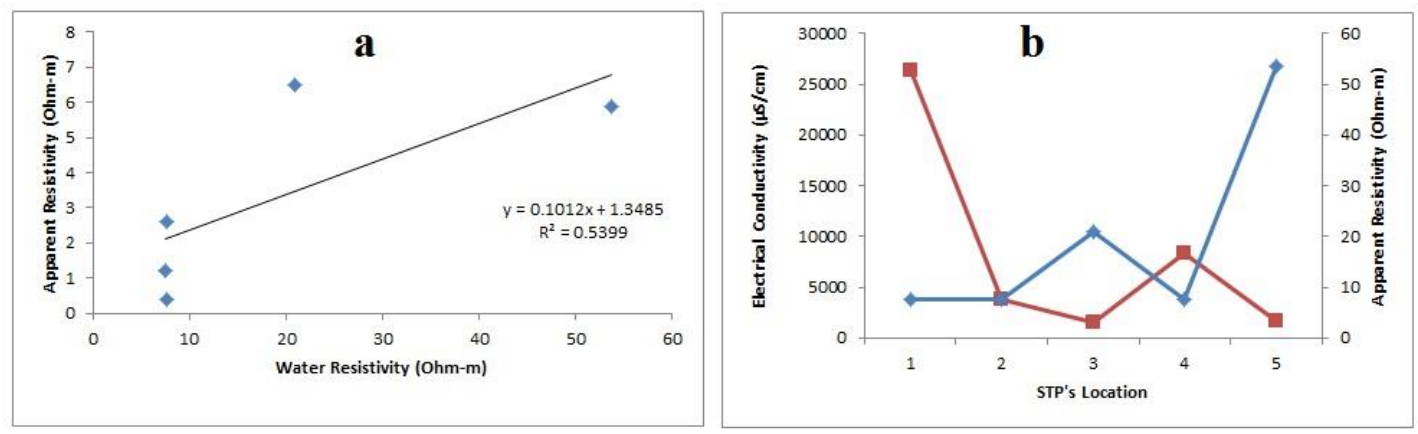

Figure 6. a) The relation between water resistivity and Apparent resistivity

b) correlation between apparent resistivity and electrical conductivity

Table 3. The aquifer (apparent) resistivity and water resistivity of the samples

\begin{tabular}{lccc}
\hline Station & Apparent Resistivity $(\Omega \mathrm{m})$ & Electrical Conductivity $\left(\mu \mathrm{S} \mathrm{m}^{-1}\right)$ & Water Resistivity $(\Omega \mathrm{m})$ \\
\hline VES 1 & 7.6 & 26400 & 0.4 \\
\hline VES 2 & 7.61 & 3810 & 2.6 \\
\hline VES 3 & 21 & 1551 & 6.3 \\
\hline VES 4 & 7.51 & 8340 & 1.7 \\
\hline VES 5 & 53.69 & 1711 & 5.9 \\
\hline
\end{tabular}

The same correlation between aquifer resistivity and EC values holds good for each other The relation between aquifer (apparent) resistivity, water resistivity $\left(\rho_{w}\right)$ and electrical conductivity (EC) of the water sample is shown below

$\rho_{w}=1 /$ EC 
where $\rho_{w}$ is the water resistivity and EC represents the electrical conductivity.

In this study the water resistivity $\left(\rho_{w}\right)$ and the aquifer (apperent) resistivity $\left(\rho_{a}\right)$ plotted on in fig. 6a gives the following empirical relationship between them:

$\rho_{a}=0.1012 \rho_{w}+1.35$

In Fig. $6 a$, the pearson's correlation coefficient value is 0.539 with a strong positive correlation between water resistivity and aquifer resistivity. In Fig. 6b, when apparent resistivity is more, Electrical conductivity of groundwater is less. While apparent resistivity is less electrical conductivity of groundwater is more. Hence apparent resistivity and electrical conductivity are indirectly proportional to each other. This shows that VES is a very useful tool to delineate groundwater contamination zones and transport paths for the source of contamination in the study area.

\section{Conclusion}

This study brought out that Vertical Electrical Sounding measurements are effective to investigate the suitability of reclaimed water recharge and to understand the groundwater conditions. The VES method is a non-destructive and appropriate method to detect depth and thickness of various subsurface geological formations and the groundwater quality within these formations. The litho-log obtained with VES data using computer software 1X1D v2 was found to be in close agreement with borehole data. The subsurface geoelectrical layers showed different resistivity values at the Chennai Metro water Sewage Treatment Plant sites due to type of formation and groundwater quality.

The geo electrical curves are prominently of $\mathrm{H}$ type indicating the presence of three layers followed by combination of curves HA and HK indicating the four sub-surface layer. Interpretation reveals, their thickness and their water bearing capacity within the study area. The resistivity varies from $3.96 \Omega \mathrm{m}$ to $2796.4 \Omega \mathrm{m}$ and thickness from $0.58 \mathrm{~m}$ to $43.05 \mathrm{~m}$. The EC value for VES 1 (Perungudi) and VES 3 (Koyambedu) are $26400 \mu \mathrm{S} \mathrm{cm}^{-1}$ and $1551 \mu \mathrm{S} \mathrm{cm}^{-1}$, the TDS value for VES 1 and VES 3 are 16,896 $\mathrm{mg} \mathrm{l}^{-1}$ and 993 respectively. From this investigation, the thickness of the first layer obtained by VES method along with clay and sand ratio is the deciding factor to assess the suitability of reclaimed water recharge. The study reveals that the Clay \% should be 30 to 40 and Sand \% should be between 60 to 70 for reclaimed water recharge. Apparent resistivity and EC are indirectly proportional to each other. Among the five STPs sites, Koyambedu and Anna University STPs are suitable for reclaimed water recharge using soil aquifer treatment.

\section{Acknowledgements}

The authors are thankful to Chennai Metropoliton Water Supply and Sewerage Board and Anna University for granting permission to conduct the geophysical survey at Chennai Metrowater Sewage Treatment Plants sites and Anna University STP site

\section{References}

Alabi A.A, Bello R.A.S, Ogungbe H.O and Oyerinde (2010), Determination of Groundwater Potential in Lagos State University, OJO; using Geoelectrical Methods (Vertical electrical sounding and horizontal profiling), Report and Opinion.

Angelakis A.N., Marecos Do Monte M.H.F., Bontoux L. and Asano T. (1996), The status of wastewater reuse practice in the Mediterranean basin; need for guidelines, Water Research, 33, 2201-2217.

Asano T and Cotruvo J.A. (2004), Groundwater recharge with reclaimed municipal wastewater; health and regulatory conditions, Water Research, 38, 1941-1951.

APHA (1989), Standard methods for the examination of water and wastewater, $19^{\text {th }}$ Edn. American Public Health Association, Washington.

Hibbs B.J. (2001), Geophysical and Hydrochemical analysis of the white rive Alluvial Aquifer, Crosby county, Texas, New Mexico Geological Society Guidebook, $52^{\text {nd }}$ field conference, Geology of the Llano Estacado. 
Central Groundwater Board, Ministry of Water Resources Government of India (2011), Groundwater Scenario in Major cities of India.

Choudhury K. and Saha D.K. (2004), Integrated geophysical and chemical study of saline water intrusion, Ground Water, 42, 671-677.

Urish D.W.(1983), The practical application of surface electrical resistivity to detection of groundwater pollution, Groundwater, 21(2), 144-152.

Kalisperi D., Soupios P., Kouli M., Barukov P., Kershaw S., Collins P. and Vallianatos F. (2009), Coastal aquifer assessment using geophysical method (TEM, VES) case study; Northern Crete, Greece. In: $3^{\text {rd }}$ IASME/WSEAS international conference on geology and seismology, Cambridge, UK.

Lashkaripour G.R. (2003), An investigation of groundwater condition by geoelectrical resistivity method: a case study in Korin aquifer, southeast Iran, Jour.Spatial Hydrology, 3, 1-5.

Stewart M., Layton M. and Lizanec T. (1983), Application of resistivity surveys to regional Hydrogeologic reconnaissance, Groundwater, 21(1), 42-48.

Mathiazhagan M, Selvakumar T. and Ganesan M. (2012), Detection of solid waste dumpsite-induced groundwater contamination leachate using electrical resistivity method, In: Sixth IAHR International groundwater Symposium, Hadi and Copty (Eds) CRC Press, Kuwait.

Mathiazhagan M., Selvakumar T. and Ganesan M. (2013), Geophysical Technique for Sensing of Solid Waste Dump Site-Induced Groundwater Contamination Leachate, Poll Res., 32(3), 509-514.

Oseji J.O., Asokhia M.B. and Okolie E.C. (2006), Determination of groundwater potential in Obiaruku and environs using surface geoelectric sounding, Environmentalist, 26, 301-308.

Palacky G.J. (1987), Clay mapping using electromagnetic methods, First Break, 5, 295-306.

Sahebrao Sonkamble (2014), Electrical Resistivity and Hydrochemical Indicators Distinguishing chemical characteristics of subsurface pollution at Cuddalore Coast, Tamilnadu, Journal Geological Society of India, 83, 535-548.

Sahebrao Sonkamble, V. Satish Kumar, B. Amarender, P.M. Dhunde, S. Sethurama and K. Raj Kumar (2014), Delineation of fresh aquifers in Tannery Belt for sustainable development - A case study from Southern India, Journal Geological Society of India, 83, 279-289.

Sahu P.C. and Sahoo H. (2006), Targeting groundwater in tribal dominated Bonai area of drought-prone Sundargarh District, Orissa, India. A combined geophysical and remote sensing approach, Jour. Hum.Ecol., 20, 109-115.

Shankar K.R. (1994), Affordable water supply and sanitation. In: Groundwater exploration $20^{\text {th }}$ WEDC Conference Colombo, Sri Lanka.

Sinkandar P., A. Bakhsh, T. Ali and M. Arshad (2010), Vertical Electrical Sounding (VES) resistivity survey technique to explore low salinity groundwater for tubewell installation in Chajdoab, J.Agric.Res., 48(4), 547-566.

Sivaraman K.R. and S. Thillaigovindarajan (2002), Manual on Rainwater Harvesting - Save Water \& Save the Nation from the Water Crisis: A Unique Feature of India's Traditional Water Harvesting Methods, Sastha Foundation, Chennai-91.

Srinivas Y., Muthuraj D., Hudson Oliver D., Stanly Raj A. and Chandrasekar (2013), Environmental applications of geophysical and geochemical methods to map groundwater quality at Tuticorin, Tamilnadu, India, Environ Earth Sci, 70(5), 2143-2152.

Stampolidis A., Tsourlos P., Soupios P., Mimides T.H., Tsokas G., Vargemezis G. and Vafidis A. (2005), Integrated geophysical investigation around the brackish spring of Rina, Kalimnos Isl., SW Greece, Jour. balk Geophys. Soc., 8(3), 63-73.

Tapias J.C., M.Himi, A.Masachs, C.Nieto, F.Brissaud and M. Salgot (2005), Using electrical imaging for assessing suitability of reclaimed water recharge, In: Integrated concepts in Water Recycling, S.J.Khan, A.I Schafer, M.H.Muston (Eds) Begur, Spain.

Zohdy A.A.R. and Martin R.J. (1993), A study of seawater intrusion using direct-current soundings in the southern part of the Oxward Plain, California. Open-File Report, USGS, 139, 93-524

Zohdy A.A.R., G.P. Eaton and D.R. Mabey (1974), Application of Surface Geophysics to Groundwater Investigations. US Geology Survey. 